\title{
Validation of three predictive equations for basal metabolic rate in adults
}

\author{
Manuel Ramirez-Zea* \\ Institute of Nutrition of Central America and Panama (INCAP), PO Box 1 188, Calzada Roosevelt, Zona 11 , \\ Guatemala City, Guatemala
}

\begin{abstract}
Objective: To cross-validate three predictive set of equations for basal metabolic rate (BMR) developed by Schofield (Schofield database), Henry (Oxford database) and Cole (Oxford database) using mean values for age, weight, height and BMR of published studies.

Design: Literature review of studies published from 1985 to March 2002.

Setting: All studies selected used appropriate methods and followed conditions that met the criteria established for basal metabolism, were performed in healthy adults, and were not part of the Schofield or Oxford database.

Subjects: A total of 261 groups of men and women from 175 studies were selected and categorised in three age groups (18.5-29.9, 30.0-59.9, $\geq 60$ years old) and three body mass index (BMI) groups (normal weight, overweight and obese).

Results: Linear regression and concordance correlation analysis showed that the three sets of equations had the same association and agreement with measured BMR, across gender, age, and BMI groups. The agreement of all equations was moderate for men and poor for women. The lowest mean squared prediction errors (MSPRs) were given by Henry equations in men and Cole equations in women. Henry and Cole equations gave lower values than Schofield equations, except for men over 60 years of age. Henry equations were the most accurate in men. None of the three equations performed consistently better in women.

Conclusion: These results support the use of Henry equations in men with a wide range of age and BMI. None of the proposed predictive equations seem to be appropriate to estimate BMR in women.
\end{abstract}

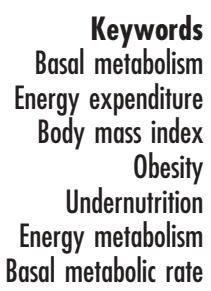

\section{Introduction}

Since 1981, the Joint Food and Agricultural Organization/ World Health Organization/United Nations University (FAO/WHO/UNU) Expert Consultation on Energy and Protein Requirements recommended expressing energy expenditure as multiples of basal metabolic rate $(\mathrm{BMR})^{1}$. The document Energy and Protein Requirements, published in 1985, reported several predictive equations for BMR developed by Schofield ${ }^{2-3}$. However, most BMR values in the Schofield database were obtained from European and North American subjects (87\%), and several reports have been published demonstrating that those equations overestimate BMR, particularly in some ethnic groups $^{4-8}$. Henry and Cole ${ }^{9-10}$ have developed new predictive equations, using a more extensive database than Schofield (Oxford database). Henry and Cole equations excluded the Italian subjects, who were overrepresented in the Schofield database (47\%) and have unusually high BMR values. Moreover, $38 \%$ of subjects in the Oxford database are from developing countries? Hence, the Oxford database has a broader geographical and ethnic representation than the Schofield database.

The purpose of this paper is to cross-validate those three predictive models (Schofield, Henry and Cole) in adults, using mean values for age, anthropometry and BMR of published studies. The analyses were performed in groups of individuals with a mean body mass index (BMI) in the normal range $\left(18.5-25.0 \mathrm{~kg} \mathrm{~m}^{-2}\right)$. Further analyses were done including groups of individuals with a mean BMI over 18.5 (normal weight, overweight, and obese groups).

\section{Methods}

A literature review was performed using MEDLINE database (National Library of Medicine, Bethesda, MD). The search covered the period from January 1985 to March 2002. The following keywords were used: basal metabolism, BMR, or resting metabolic rate, all limited to human subjects. Additional articles were obtained from the list of 
references of few papers. A total of 2286 articles were electronically transferred to ProCite 3.1 (Personal Bibliographic Software, Inc., Michigan), for reference management.

The exclusion criteria used to select papers for their analysis were:

1. Non-original papers, published twice or more for the same individuals. Consequently, I excluded review papers (320), letters to the editor (40), meta-analysis and compilations of several studies (18), and studies based on subjects whose results were published in other papers (45).

2. Studies that were part of the Oxford database (20). None of the papers were part of the Schofield database, since those papers were published prior to 1985.

3. Studies where the abstract said that BMR was not measured, or was measured exclusively in ill or burned persons, hospitalised or during administration of anaesthetic (1007).

4. Studies done exclusively on children or adolescents, obese persons, pregnant women, early post-partum, or athletes (210).

5. Studies that did not show data separating men from women, or did not report age, weight, or non-adjusted BMR of subjects (79).

6. Since the mean value of each age and gender group was used, it was decided to exclude from analysis studies with less than 10 individuals of a given age and gender (252).

7. Methods and environmental and subjects' conditions followed to measure BMR were carefully reviewed in each study to make sure that criteria for BMR were accomplished. Twenty-seven studies were excluded due to inappropriate methodology.

Excluding all articles that met any of the above criteria, plus another 86 articles that were not possible to obtain by the time the analysis was started, and five studies with BMR values considered as outliers by the Tukey method (median \pm twice the interquantile range) $^{11}$, a total of 175 studies remained for analysis. Several of those studies included more than one age and gender group, for example, men 18-30 and men 30-65. Table 1 summarises the number of groups of subjects in each gender, age and BMI category. Underweight groups were not included in the analysis due to the low number of groups available. The age groups selected for both sexes are the same used by Schofield et al. for the development of their predictive equations (Table 2). All references used in the analysis are listed in Annex 1.

\section{Predictive equations}

The Schofield equations were derived from 7173 individual BMR data (4809 men, 2364 women), 0-100 years of age, from 114 studies published between 1914
Table 1 Group of subjects in each gender, age and body mass index (BMI) category

\begin{tabular}{|c|c|c|c|c|c|}
\hline \multirow[b]{2}{*}{ Age (years) } & \multicolumn{5}{|c|}{ BMI $\left(\mathrm{kgm}^{-2}\right)$} \\
\hline & $\begin{array}{c}\text { Underweight } \\
<18.5\end{array}$ & $\begin{array}{c}\text { Normal } \\
\text { weight } \\
18.5-25.0\end{array}$ & $\begin{array}{l}\text { Overweight } \\
25.1-30.0\end{array}$ & $\begin{array}{l}\text { Obese } \\
>30.0\end{array}$ & $\begin{array}{c}\text { All } \\
\geq 18.5\end{array}$ \\
\hline \multicolumn{6}{|l|}{ Men } \\
\hline $18.0-29.9$ & 5 & 50 & 9 & 2 & 61 \\
\hline $30.0-59.9$ & 0 & 19 & 16 & 9 & 44 \\
\hline$\geq 60.0$ & 0 & 8 & 17 & 0 & 25 \\
\hline All & 5 & 77 & 42 & 11 & 130 \\
\hline \multicolumn{6}{|l|}{ Women } \\
\hline $18.0-29.9$ & 2 & 49 & 4 & 4 & 57 \\
\hline $30.0-59.9$ & 1 & 38 & 12 & 9 & 59 \\
\hline$\geq 60.0$ & 0 & 7 & 5 & 3 & 15 \\
\hline All & 3 & 94 & 21 & 16 & 131 \\
\hline
\end{tabular}

and 1980 (Table 2) ${ }^{3}$. Peculiarities of this database are that $57 \%$ of men and $27 \%$ of women were from Italy; the Italian group appears to have a higher $\mathrm{BMR} \mathrm{kg}^{-1}$ body weight than any other Caucasian group; most studies used closed-circuit methods that usually lead to higher BMR values compared to open-circuit methods; and most of the studies were done in European and North American subjects, containing relatively few subjects from developing countries (13\%).

The Henry equations were obtained from 10502 individual BMR values (5794 men, 4708 women), 0-106 years of age, from 166 published (1914-2001) and unpublished studies (Oxford database) ${ }^{9}$. The Cole equations were also developed from this database (Table 2).

The Oxford database included only healthy subjects (malnourished or sick subjects were excluded), although overweight and obese subjects were not eliminated. It considers the Italian subjects of the Schofield database, although Henry did not include them to derive his equations. The Oxford and Schofield databases have 4039 data points in common (77 papers). However, 38\% of subjects (4018) in the Oxford database lived in developing countries. The later database also included $53 \%$ of studies that used open-circuit calorimetry.

The Henry and Schofield equations assumed a linear association between BMR and weight. It is worth noting that weight reduces the total variation in BMR by $90-93 \%$ in children $0-3$ years of age; however, as age increases, this total variation explained by weight decreases, being the lowest in the 30-60-year-old group (36 and 46\% for men and women, respectively, by Schofield's equations and 51 and $57 \%$ by Henry's equations). Both authors, however, demonstrated that the inclusion of height in the equation did not improve its prediction ability significantly.

Cole developed another set of equations only for adults, 18-80 years old, which avoid any discontinuities between age groups ${ }^{12}$. He used the Oxford database, as Henry did, but he did not exclude the Italian subjects. Cole's models predict In BMR using age, ln weight and ln height as independent variables, adjusted for differences in mean 
Table 2 Predictive equations for basal metabolic rate (BMR, MJ day ${ }^{-1}$ ) applied in the analysis*

\begin{tabular}{|c|c|c|c|c|c|c|}
\hline \multirow[b]{2}{*}{ Age (years) } & \multicolumn{2}{|r|}{ Schofield } & \multicolumn{2}{|r|}{ Henry } & \multicolumn{2}{|r|}{ Cole $^{\ddagger}$} \\
\hline & $n^{\star *}$ & Equations & $n^{\star *}$ & Equations & $n^{\star *}$ & Equations \\
\hline Men & 4809 & & 5794 & & & \\
\hline $0-2.9$ & 162 & $0.249 \times W t-0.127$ & 277 & $0.255 \times \mathrm{Wt}-0.141$ & & \\
\hline $3.0-9.9$ & 338 & $0.095 \times W t+2.110$ & 289 & $0.0937 \times W t+2.15$ & & \\
\hline $10.0-17.9$ & 734 & $0.074 \times W t+2.754$ & 863 & $0.0769 \times W t+2.43$ & & \\
\hline $18.0-29.9$ & 2879 & $0.063 \times W t+2.896$ & 2821 & $0.0669 \times W t+2.28$ & & $e^{-0.1631-0.00255 \times \mathrm{Age}+0.4721 \times \ln \mathrm{Wt}+0.2952 \times \ln \mathrm{Ht}}$ \\
\hline $30.0-59.9$ & 646 & $0.048 \times W t+3.653$ & 1010 & $0.0592 \times W t+2.48$ & 1207 & \\
\hline$\geq 60.0$ & 50 & $0.049 \times W t+2.459$ & & & & or \\
\hline $60.0-69.9$ & & & 270 & $0.0543 \times W t+2.37$ & & \\
\hline$\geq 70.0$ & & & 264 & $0.0573 \times W t+2.01$ & 6425 & $e^{-0.2630-0.00277 \times A g e+0.4877 \times \ln \mathrm{Wt}+0.3367 \times \ln \mathrm{Ht}}$ \\
\hline Women & 2364 & & 4708 & & & \\
\hline $0-2.9$ & 137 & $0.244 \times W t-0.130$ & 215 & $0.246 \times W t-0.0965$ & & \\
\hline $3.0-9.9$ & 413 & $0.085 \times W t+2.033$ & 403 & $0.0842 \times W t+2.12$ & & \\
\hline $10.0-17.9$ & 575 & $0.056 \times W t+2.898$ & 1063 & $0.0465 \times W t+3.18$ & & \\
\hline $18.0-29.9$ & 829 & $0.062 \times W t+2.036$ & 1664 & $0.0546 \times W t+2.33$ & & \\
\hline $30.0-59.9$ & 372 & $0.034 \times W t+3.538$ & 1023 & $0.0407 \times \mathrm{Wt}+2.90$ & 1030 & $e^{-0.1934-0.00199 \times A g e+0.4764 \times \ln W t+0.0194 \times \operatorname{ln~Ht}}$ \\
\hline$\geq 60.0$ & 38 & $0.038 \times W t+2.755$ & & & & or \\
\hline $60.0-69.9$ & & & 185 & $0.0429 \times W t+2.39$ & & \\
\hline$\geq 70.0$ & & & 155 & $0.0417 \times W t+2.41$ & 3224 & $e^{-0.0713-0.00209 \times A g e+0.4075 \times \ln W t+0.3540 \times \operatorname{ln~Ht}}$ \\
\hline
\end{tabular}

*Wt - weight $(\mathrm{kg})$; Ht - Height $(\mathrm{m})$.

**Sample size used for development of each regression model.

‡First equation (restricted to 18-80 years of age, body mass index (BMI) $18.5-24.9 \mathrm{~kg} \mathrm{~m}^{-2}$, published after 1950, using open-circuit calorimetry, and adjusted for study differences in mean BMR) was used in the analysis of subjects with mean BMI between 18.5 and 25.0. Second equation (restricted only to 18-80 years of age and adjusted for study differences in mean BMR) was used when overweight and obese subjects were included in the analysis.

BMR (also adjusted for age, weight, and height) between studies. Cole also created models limited to subjects with normal BMI $\left(18.5-24.9 \mathrm{~kg} \mathrm{~m}^{-2}\right)$, to those same subjects but from studies published after 1950 and all the above conditions plus restricted to open-circuit methods. Those conditions eliminated the Italian subjects, who were measured by a closed-circuit technique between the years 1936-1942. Cole's restricted model was applied to the analysis of a group of subjects with mean BMI between 18.5 and 25.0. The full model was used when overweight and obese subjects were also included in the analysis.

\section{Analysis}

All analyses were done using the mean values for BMR, age, weight, height, and BMI published in each article. Results are reported as mean $\pm \mathrm{SD}$. Linear regression analysis (to test for precision), concordance correlation (to test for accuracy) ${ }^{12}$, and analysis of variance (to further test for accuracy) were used to compare predicted BMR by each set of equations with measured BMR and among each other. The best model was considered with the lowest mean squared prediction error (MSPR), a better indicator of how well the model predicts in another data set than standard error of the estimate (SEE) $)^{13}$.

\section{Results}

The first analysis was done in age and gender groups with a mean BMI between 18.5 and $25.0 \mathrm{~kg} \mathrm{~m}^{-2}$. Table 3 contains characteristics of the groups of subjects included in this analysis. BMR was lower in women that in men.
The group of individuals over 60 years of age had a lower BMR than younger groups.

Linear regression and concordance correlation analysis revealed that the three sets of predictive equations had the same association and agreement with measured BMR, across gender and age groups (Table 4). Overall and stratified by age, concordance correlation coefficients were between 0.6 and 0.8 in me, meaning that all equations are moderately precise and accurate to predict BMR. In the case of women, all predictive equations had a poor association and agreement with measured BMR, particularly in the 3059.9-year-old group (Table 4). The lowest MSPR was given by Henry's equations in men and Cole's equations in women.

BMR values predicted by the three equations, as expected, were highly correlated ( $r$ values between 0.92 and 1.00, Table 4). Schofield and Henry equations for men and women between 18.0 and 59.9 years old had correlation coefficients of 1 and their association with measured BMR were identical. However, the concordance coefficients between those two equations varied among 0.56 and 0.92 , meaning that the association between them is a straight line, but one equation gives values that under or overestimate the values of the other. In this case, the Henry equations showed slightly lower predicted values than the Schofield equations, except for men over 60 years of age (Table 5).

Since all predictive equations resulted in the same precision and accuracy, analysis of variance was performed to test for accuracy only. Levene's test was done to verify for homogeneity of variances, showing that variances among groups were not different. This condition allows the use of analysis of variance. 


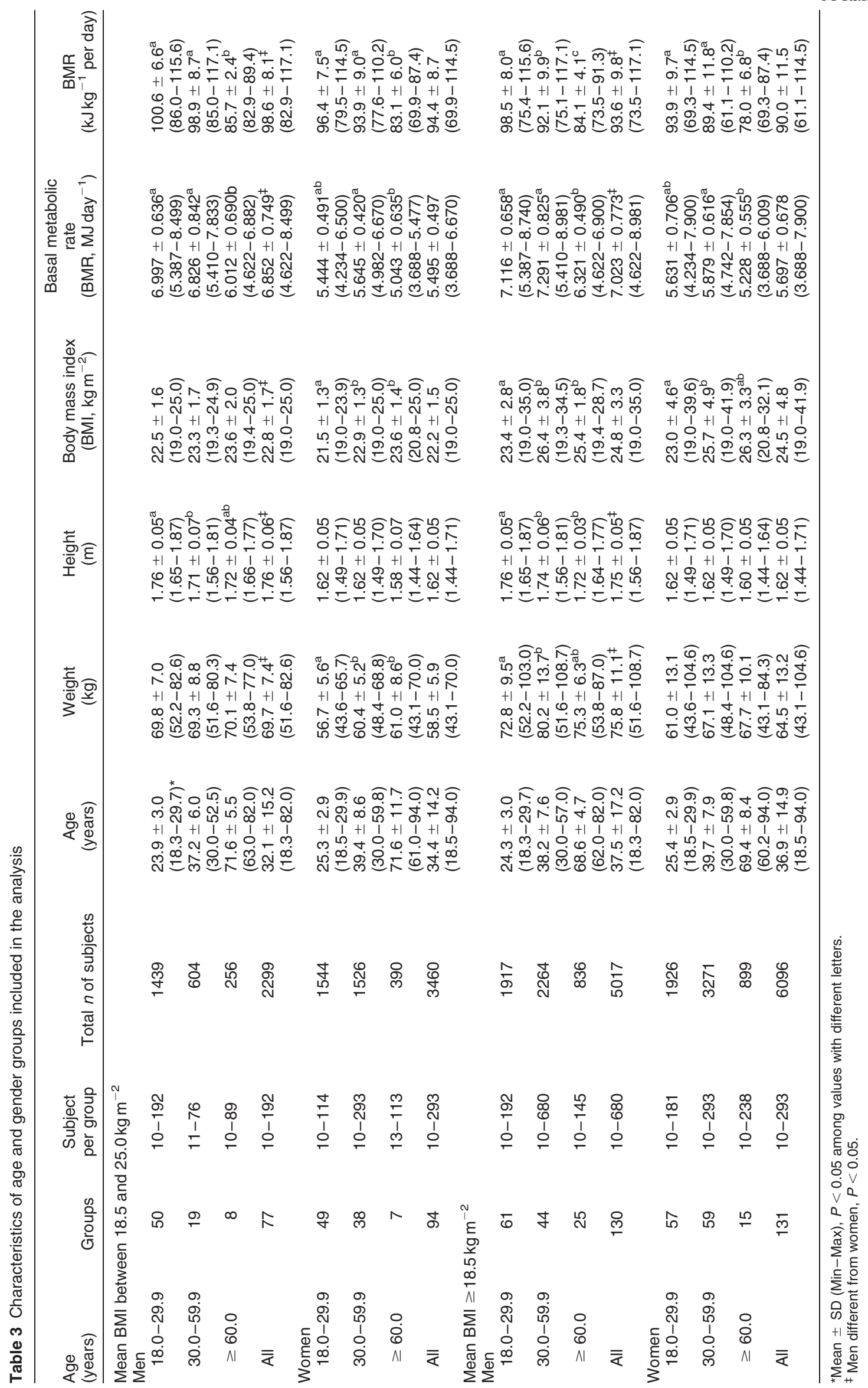




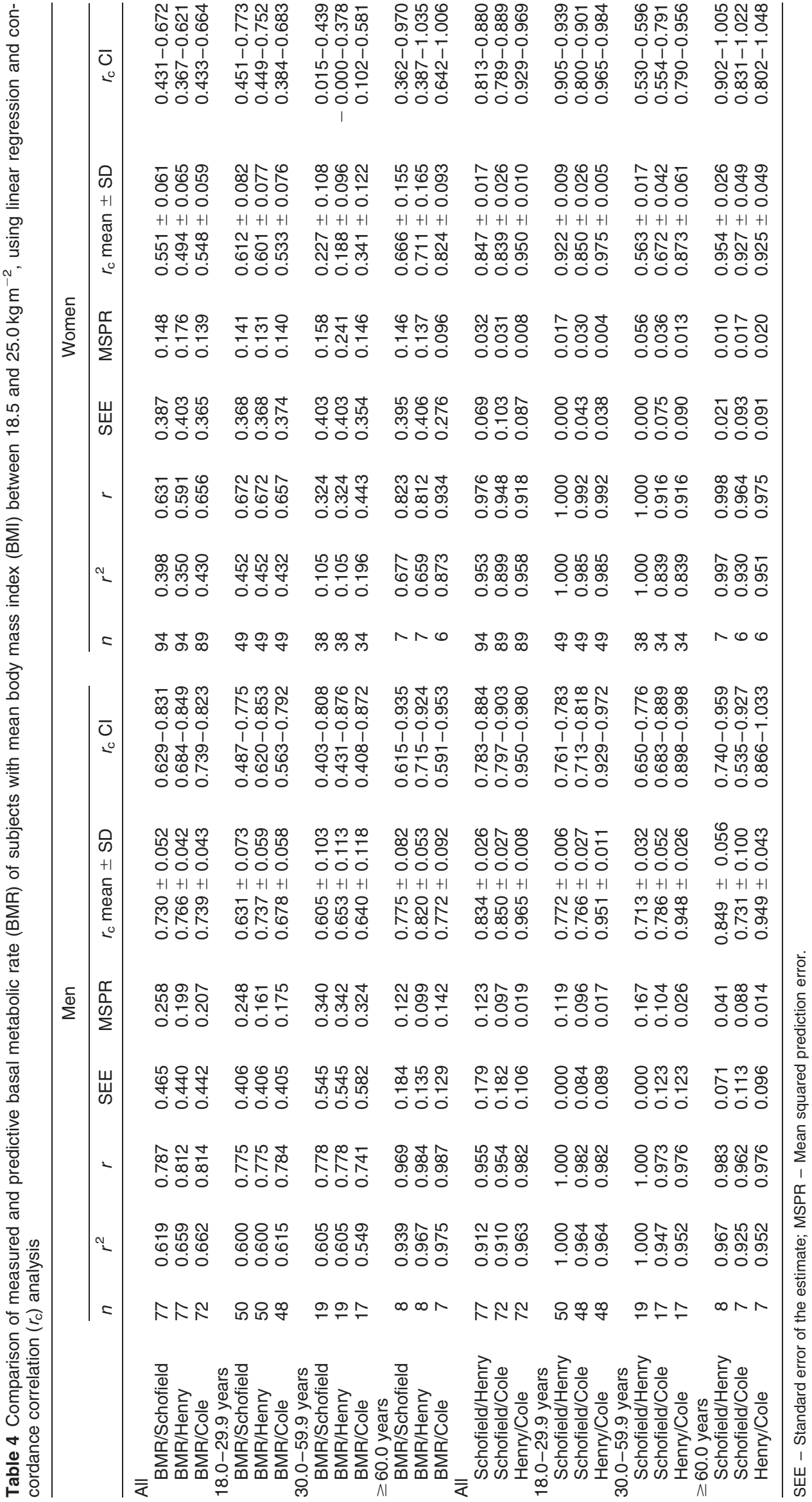


Table 5 contains the predicted BMR values using the Schofield, Henry and Cole equations, for each gender and age group. Overall, there were no differences among absolute values of measured BMR and predicted BMR by each method in men and women. However, predicted BMR by the Schofield equations was higher than predicted BMR by the Henry equations in men, and by the Henry and Cole equations in women. The only other difference found in men was in the 18-29.9-year-old group, where predicted BMR by the Schofield equations was greater than measured BMR. Conversely, predicted BMR by the Henry and Cole equations in women 30-59.9 years old resulted in lower than measured BMR.

The absolute and relative difference values among measured BMR and each predictive equation revealed that the Schofield equations overestimate BMR in men (3.7\%), particularly in the 18-29.9-year-old group (4.6\%), and the Henry equations underestimate BMR in women (1.8\%), particularly in the 30-59.9-year-old group (4.6\%, Table 5). Furthermore, Henry and Cole's equations gave consistently lower values than the Schofield equations, except for men over 60 years of age.

A second set of analysis included an overweight and obese group of subjects, according to their mean BMI values (25.1-30.0 and $>30.0 \mathrm{~kg} \mathrm{~m}^{-2}$, respectively). BMR decreased with age in both men and women (Table 3 ). Table 6 shows the linear regression and concordance correlation analysis when normal, overweight and obese groups were combined. The addition of the overweight and obese groups of men did not make any difference in the association and agreement found in the group of men with normal mean BMI alone. On the contrary, the association and agreement improved significantly when the overweight and obese groups of women were combined with normal BMI groups (Table 6 and Fig. 1).

The analysis of variance results when overweight and obese groups of subjects were included are presented in Table 5. When the overweight and obese groups of men were incorporated, the BMR overestimation by the Schofield equations was more evident and the Henry and Cole equations persisted as equally accurate. In the case of women, the BMR underestimation by the Henry equations in the 30-59.9-year-old age group disappeared (Table 5). The Henry and Cole equations continued giving lower values than the Schofield equations, except for men over 60 years of age.

Figure 2 shows the scatter plots among measured BMR and predicted BMR by the Schofield, Henry, and Cole equations in Caucasian (37 groups of men and 40 groups of women) and non-Caucasian ( 41 groups of men and 51 groups of women) subjects with BMI between 18.5 and 25.0. Non-Caucasian groups included African, Amerindian, Caribbean, Indian, Hispanic, Malaysian, Oriental, and Polynesian. Caucasian groups included White and Black American. All groups in which ethnicity was not reported or various ethnic groups were included, were not considered here. Non-Caucasians had significantly lower BMR values than Caucasians ( $6.17 \pm 0.68$ and $7.12 \pm 0.62 \mathrm{MJday}^{-1}$ in men, and $5.18 \pm 0.52$ and $5.76 \pm 0.44$ in women, $P<0.01$ ) and non-Caucasian values corresponded to most of the lowest BMR values (Fig. 2). Henry's equations fit better Caucasian and nonCaucasian groups than the Schofield and Cole equations in men.

\section{Discussion}

The main findings of this validation study were that, in men, the three sets of equations developed by Schofield, Henry, and Cole, are equally precise, but the Henry and Cole equations were more accurate, since Schofield's equations tend to overestimate BMR. For simplicity, this finding diminishes the significance of recommending the more complex equations developed by Cole, leaving the Henry equations as the best set of equations for men. This conclusion is valid for a group of subjects whose mean BMI classified them as normal weight, overweight, or obese. The degree of association and SEE were similar to the association and SEE reported by Schofield and Cole in their papers ${ }^{9-10}$.

In women, the results are not that clear, probably related to the poor association and agreement found with all equations validated. As in previous reports ${ }^{3,9}$, weight diminishes the total variation in BMR by $62-66 \%$ in men. In women, however, the total variation in BMR explained by weight was only $35-43 \%$, and only $10-19 \%$ in the $30-$ 60-year-old group. Apparently this poor association vanished when overweight and obese groups of subjects were included in the analysis. However, that circumstance is probably explained by a leverage effect of the upper data points corresponding to obese subjects (Fig. 1). More data is needed on obese women to clarify this point. None of the proposed predictive equations seem to be appropriate to estimate BMR from mean population weight values in women. The logarithmic transformation used in the Cole equations did not improve the prediction accuracy and precision.

The results obtained in women may also be accounted for by a non-linear association between weight and BMR, or weight not being the main variable that can explain BMR variation. A logarithmic transformation, as in Cole's equations, did not improve the prediction ability of the model. A suggestion to improve the model is conducting a piecewise regression ${ }^{13}$; in other words, allow the linear regression line to have a break-point. Observing Fig. 1 in more detail, it seems that the predicted values for women overestimated BMR in most cases when BMR was less than approximately $5.4 \mathrm{MJ} \mathrm{day}^{-1}$. The break-point for the parameter used in the equations (body weight) can be determined by examining a scatter plot between BMR 


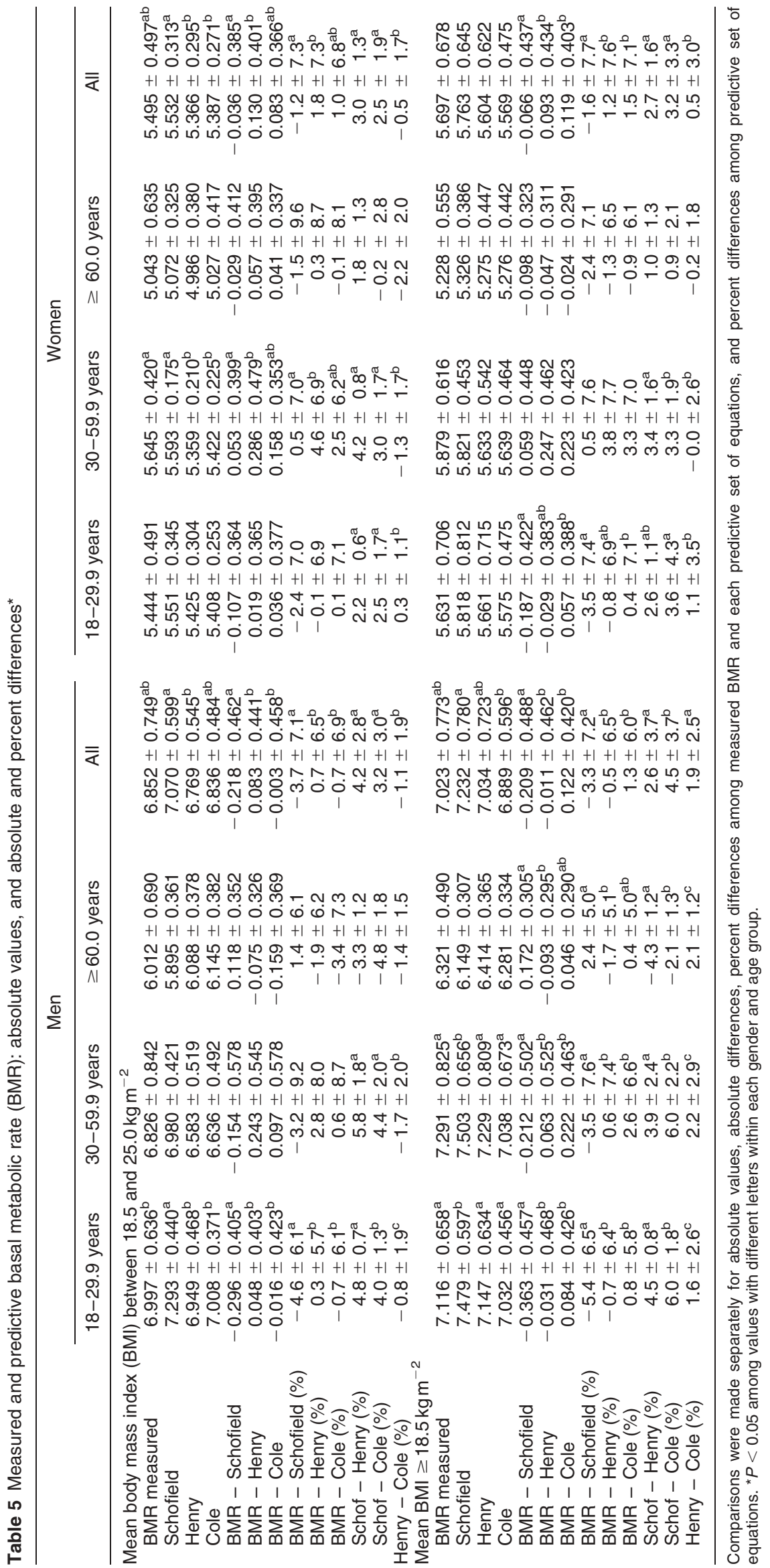




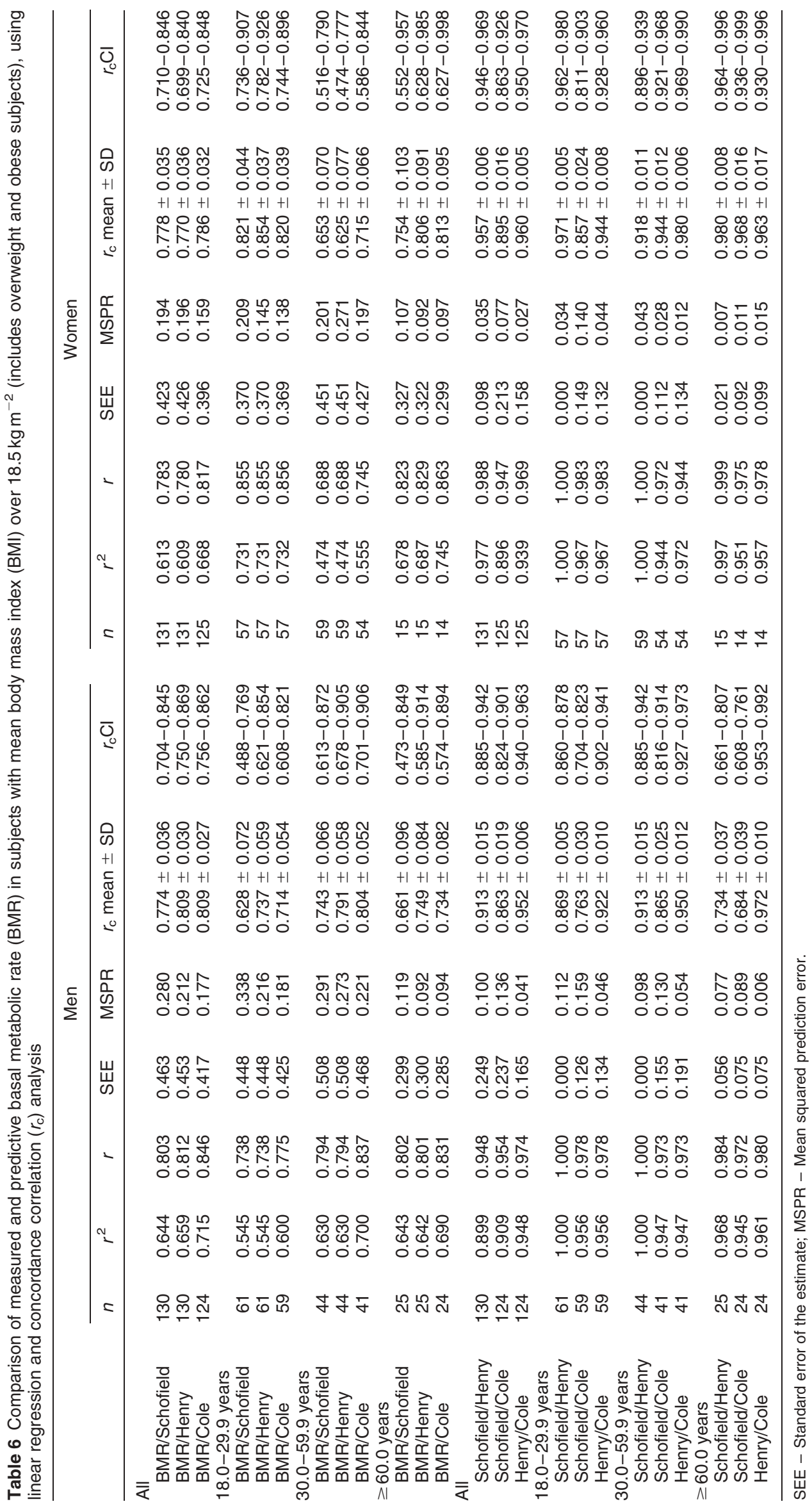


Men
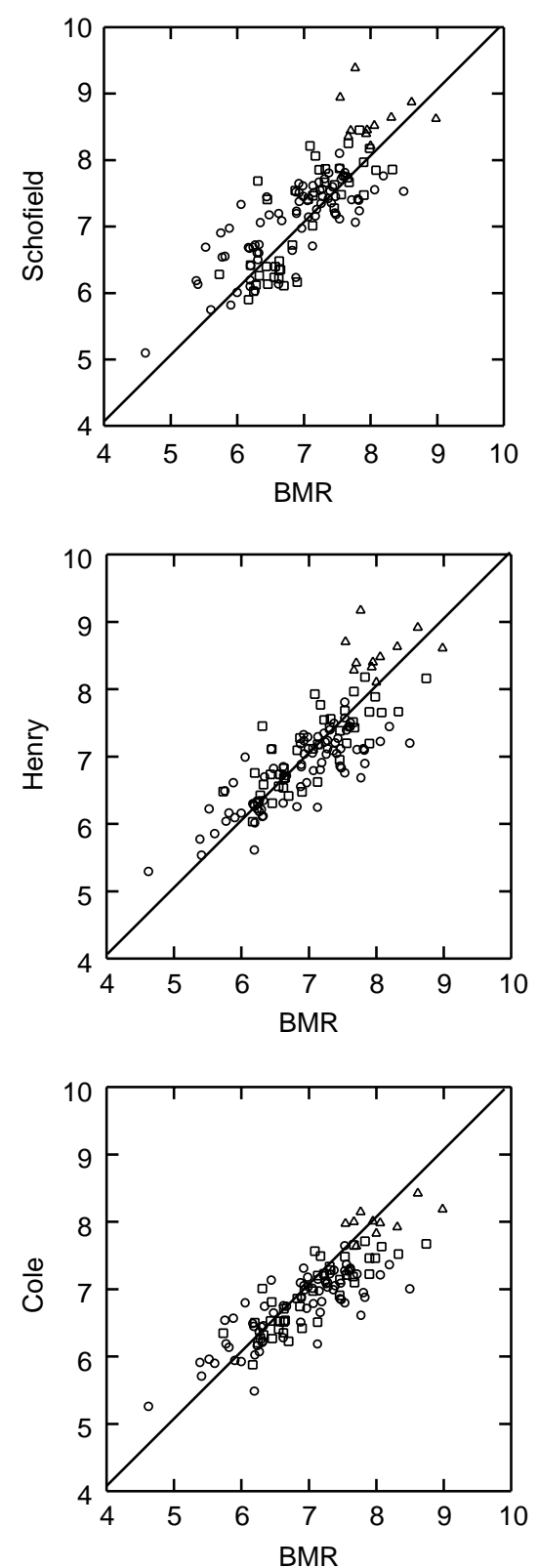
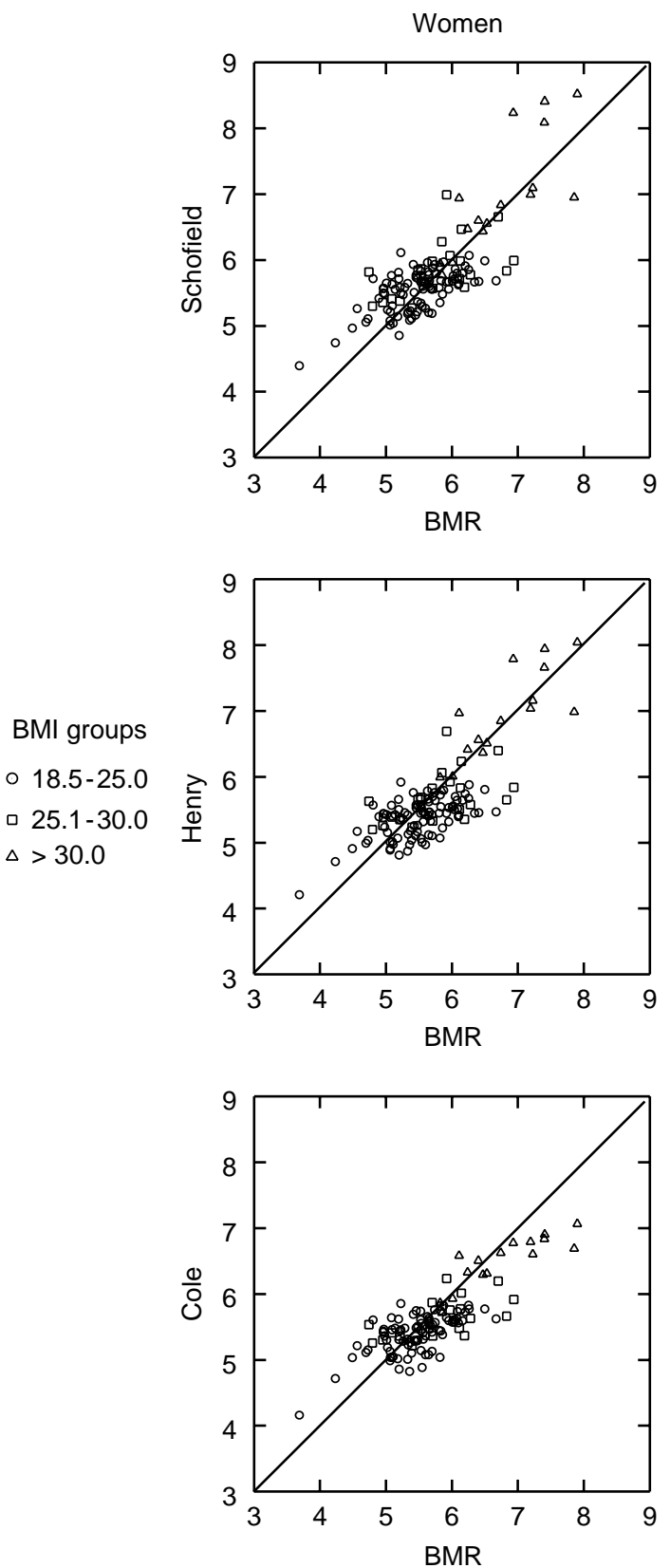

Fig. 1 Scatter plots among measured and predictive basal metabolic rate by each set of equations (Schofield, Henry and Cole) of group of subjects with mean body mass index (BMI) over $18.5 \mathrm{~kg} \mathrm{~m}^{-2}$ (includes overweight and obese groups)

and body weight and fitting a locally weighted smoothing function to the data.

The Henry and Cole equations had a better concordance coefficient than Schofield's equations with any of them (confidence intervals do not intersect), probably because the former equations were generated from the same database.

A limitation of the study was that the validation exercise was conducted using mean values for age, anthropometry, and BMR rather than on individual data, due mainly to lack of individual data from all studies included in the analysis. Nevertheless, the use of BMR predictive equations is for the estimation of energy requirements and recommendations, which were developed for their application in populations ${ }^{2}$.

Figure 2 shows that most of the non-Caucasian group of subjects had the lowest BMR values. The previously reported overestimation of BMR by Schofield's equations in several ethnic groups, particularly from developing regions ${ }^{4-9}$, is also demonstrated in men with the present data.

In conclusion, although there were no differences in agreement among the three sets of equations, the accuracy of Henry's equations was better in men and of 

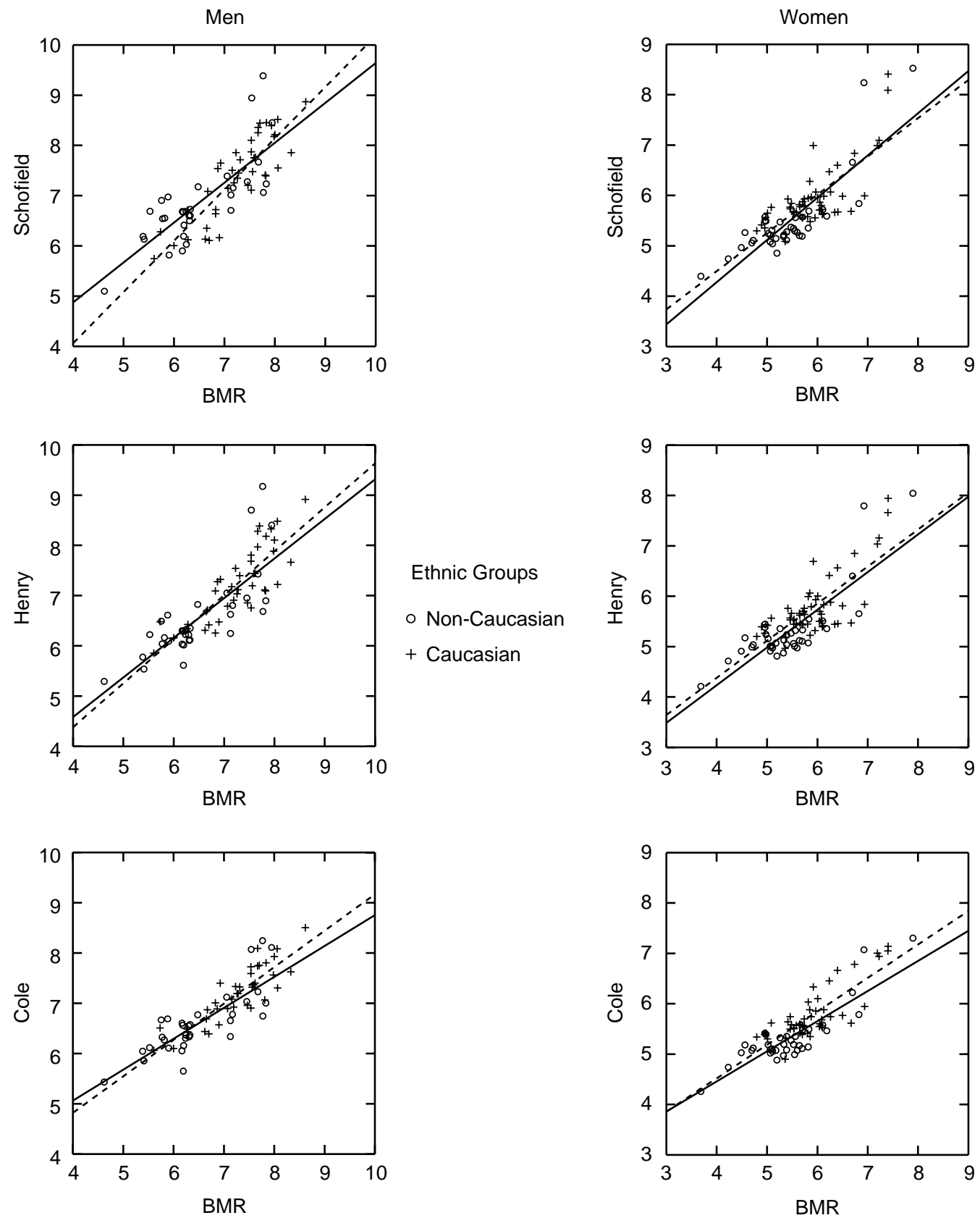

Fig. 2 Scatter plots among measured basal metabolic rate and Schofield, Henry, and Cole predictive equations for non-Caucasian (continuous fit line) and Caucasian (dotted fit line) group of subjects with mean body mass index (BMI) between 18.5 and $25.0 \mathrm{~kg} \mathrm{~m}^{-2}$

Schofield's equations in women. Furthermore, the MSPR was lowest for Henry's equations in men and Cole's equations in women. These results support the use of Henry's equations in men. The inconsistency in women might be related to the poor association between predictive and measured BMR.

\section{Acknowledgements}

I thank Zachary Towne-Smith for his collaboration with data management, Jorge Matute for his assistance with the statistical analysis, and Benjamin Torun for helpful comments during the data analysis and revision of the manuscript.

\section{References}

1 Durnin JV. Basal Metabolic Rate in Man. Working paper submitted to the Joint FAO/WHO/UNU Expert Consultation on Energy and Protein Requirements. Rome: FAO, 1981.

2 FAO/WHO/UNU. Energy and Protein Requirements. Report of a Joint FAO/WHO/UNU Expert Consultation. Technical Report Series No.724. Geneva: World Health Organization, 1985. 
3 Schofield C. An annotated bibliography of source material for basal metabolic rate data. Human Nutrition: Clinical Nutrition 1985; 39(Suppl. 1): 42-91.

4 Henry CJ, Rees DG. New predictive equations for the estimation of basal metabolic rate in tropical peoples. European Journal of Clinical Nutrition 1991; 45: 177-85.

5 Soares MJ, Shetty PS. Validity of Schofield's predictive equations for basal metabolic rates of Indians. The Indian Journal of Medical Research 1988; 88: 253-60.

6 de Boer JO, van Es AJ, Voorrips LE, Blokstra F, Vogt JE. Energy metabolism and requirements in different ethnic groups. European Journal of Clinical Nutrition 1988; 42: 983-97.

7 Valencia ME, Moya SY, McNeill G, Haggarty P. Basal metabolic rate and body fatness of adult men in northern Mexico. European Journal of Clinical Nutrition 1994; 48: 205-11.

8 Cruz CM, da Silva AF, dos Anjos LA. Basal metabolic rate is overestimated by predictive equation in college-age women of Rio de Janeiro, Brazil. Archivos Latinoamericanos de Nutricion 1999; 49: 232-7.

9 Henry CJK. Basal Metabolic Rate Studies in Humans: Measurement and Development of New Equations. Background document prepared for the Joint FAO/WHO/UNU Expert Consultation on Energy in human nutrition. Rome: FAO, 2001.

10 Cole TJ, Henry CJK. The Oxford Brookes Basal Metabolic Rate Database - A Reanalysis. Report commissioned by FAO for the Joint FAO/WHO/UNU Expert Consultation on Energy in human nutrition. Rome: FAO, 2002.

11 Tukey J. Explanatory Data Analysis. California: AddisonWesley, 1977.

12 Lin LK. A concordance correlation coefficient to evaluate reproducibility. Biometrics 1989; 45: 255-68.

13 Neter J, Waserman W, Kutner MH. Applied Linear Statistical Models: Regression, Analysis of Variance, and Experimental Designs, 3rd ed. Illinois: Richard D Irwin Inc., 1990.

Annex 1 References of all studies used in the analysis.

1 Aleman-Mateo H, Reza-Duran GT, Esparza J, Valencia ME. Energy requirements in active elderly individuals living in a rural region of Northwest Mexico. Archivos Latinoamericanos de Nutricion 1999; 49: 121-9.

2 Anjos LA, Ferreira JA. The evaluation of the physiological workload in the Brazilian legislation should be revised! The case of garbage collectors in Rio de Janeiro. Cadernos de Saude Publica: Ministerio da Saude, Fundacao Oswaldo Cruz, Escola Nacional de Saude Publica. 2000; 16: 785-90.

3 Arciero PJ, Goran MI, Gardner AM, Ades PA, Tyzbir RS, Poehlman ET. A practical equation to predict resting metabolic rate in older females. Journal of the American Geriatrics Society 1993; 41: 389-95.

4 Arciero PJ, Goran MI, Gardner AW, Ades PA, Tyzbir RS, Poehlman ET. A practical equation to predict resting metabolic rate in older men. Metabolism: Clinical and Experimental 1993; 42: 950-7.

5 Arciero PJ, Hannibal NS 3rd, Nindl BC, Gentile CL, Hamed J, Vukovich MD. Comparison of creatine ingestion and resistance training on energy expenditure and limb blood flow. Metabolism Clinical and Experimental 2001; 50: 1429-34.

6 Astrup A, Buemann B, Toubro S, Ranneries C, Raben A. Low resting metabolic rate in subjects predisposed to obesity: a role for thyroid status. American Journal of Clinical Nutrition 1996; 63: 879-83.

7 Ategbo EA, van Raaij JM, de Koning FL, Hautvast JG. Resting metabolic rate and work efficiency of rural Beninese women: a 2-y longitudinal study. American Journal of Clinical Nutrition 1995; 61: 466-72.
8 Ballor DL, Poehlman ET. Resting metabolic rate and coronary-heart-disease risk factors in aerobically and resistance-trained women. American Journal of Clinical Nutrition 1992; 56: 968-74.

9 Bathalon GP, Hays NP, McCrory MA, Vinken AG, Tucker KL, Greenberg AS, Castaneda C, Roberts SB. The energy expenditure of postmenopausal women classified as restrained or unrestrained eaters. European Journal of Clinical Nutrition 2001; 55: 1059-67.

10 Beer WH, Murray E, Oh SH, Pedersen HE, Wolfe RR, Young VR. A long-term metabolic study to assess the nutritional value of and immunological tolerance to two soy-protein concentrates in adult humans. American Journal of Clinical Nutrition 1989; 50: 997-1007.

11 Bender PR, Martin BJ. Ventilatory and treadmill endurance during acute semistarvation. Journal of Applied Physiology 1986; 60: 1823-7.

12 Benedek C, Berclaz PY, Jequier E, Schutz Y. Resting metabolic rate and protein turnover in apparently healthy elderly Gambian men. American Journal of Physiology 1995; 268: E1083-8.

13 Black AE, Bingham SA, Johansson G, Coward WA. Validation of dietary intakes of protein and energy against 24 hour urinary $\mathrm{N}$ and DLW energy expenditure in middleaged women, retired men and post-obese subjects: comparisons with validation against presumed energy requirements. European Journal of Clinical Nutrition 1997; 51: $405-13$

14 Boivin M, Camirand A, Carli F, Hoffer LJ, Silva JE. Uncoupling protein-2 and-3 messenger ribonucleic acids in adipose tissue and skeletal muscle of healthy males: variability, factors affecting expression, and relation to measures of metabolic rate. Journal of Clinical Endocrinology and Metabolism 2000; 85: 1975-83.

15 Bonnefoy M, Normand S, Pachiaudi C, Lacour JR, Laville M, Kostka T. Simultaneous validation of ten physical activity questionnaires in older men: a doubly labelled water study. Journal of the American Geriatrics Society 2001; 49: 28-35.

16 Broeder CE, Burrhus KA, Svanevik LS, Wilmore JH. The effects of aerobic fitness on resting metabolic rate. American Journal of Clinical Nutrition 1992; 55: 795-801.

17 Bronstein MN, Mak RP, King JC. Unexpected relationship between fat mass and basal metabolic rate in pregnant women. British Journal of Nutrition 1996; 75: 659-68.

18 Buchholz AC, Rafii M, Pencharz PB. Is resting metabolic rate different between men and women? British Journal of Nutrition 2001; 86: 641-6.

19 Buchowski MS, Simmons LA, Chen KY, Flakoll PJ, Mellen BG, Turner EA. Plasma leptin association with body composition and energy expenditure in sickle cell disease. Journal of the American College of Nutrition 2000; 19: 228-36.

20 Butte NF, Barbosa L, Villalpando S, Wong WW, Smith EO. Total energy expenditure and physical activity level of lactating Mesoamerindians. Journal of Nutrition 1997; 127: 299-305.

21 Butte NF, Hopkinson JM, Mehta N, Moon JK, Smith EO. Adjustments in energy expenditure and substrate utilization during late pregnancy and lactation. American Journal of Clinical Nutrition 1999; 69: 299-307.

22 Butte NF, Wong WW, Hopkinson JM. Energy requirements of lactating women derived from doubly labelled water and milk energy output. Journal of Nutrition 2001; 131: 53-8.

23 Capristo E, Addolorato G, Mingrone G, De Gaetano A, Greco AV, Tataranni PA, Gasbarrini G. Changes in body composition, substrate oxidation, and resting metabolic rate in adult celiac disease patients after a $1-y$ gluten-free diet treatment. American Journal of Clinical Nutrition 2000; 72: 76-81. 
24 Carpenter WH, Fonong T, Toth MJ, Ades PA, CallesEscandon J, Walston JD, Poehlman ET. Total daily energy expenditure in free-living older African-Americans and Caucasians. American Journal of Physiology 1998; 274: E96-101.

25 Censi L, Toti E, Pastore G, Ferro-Luzzi A. The basal metabolic rate and energy cost of standardised walking of short and tall men. European Journal of Clinical Nutrition 1998; 52: $441-6$

26 Chen WJ, Chung YC. Energy expenditure in patients with hepatocellular carcinoma. Cancer 1994; 73: 590-5.

27 Chiplonkar SA, Agte VV, Gokhale MK, Kulkarni VV, Mane ST. Energy intake and resting metabolic rate of young Indian men and women. Indian Journal of Medical Research 1992; 96: 250-4.

28 Christin L, O'Connell M, Bogardus C, Danforth E Jr, Ravussin E. Norepinephrine turnover and energy expenditure in Pima Indian and white men. Metabolism Clinical and Experimental 1993; 42: 723-9.

29 Clark D, Tomas F, Withers RT, et al. No major differences in energy metabolism between matched and unmatched groups of 'large-eating' and 'small-eating' men. British Journal of Nutrition 1993; 70: 393-406.

30 Clark HD, Hoffer LJ. Reappraisal of the resting metabolic rate of normal young men. American Journal of Clinical Nutrition 1991; 53: 21-6.

31 Cooling J, Blundell J. Differences in energy expenditure and substrate oxidation between habitual high fat and low fat consumers (phenotypes). International Journal of Obesity and Related Metabolic Disorders: Journal of the International Association for the Study of Obesity 1998; 22: 612-8.

32 Cordain L, Bryan ED, Melby CL, Smith MJ. Influence of moderate daily wine consumption on body weight regulation and metabolism in healthy free-living males. Journal of the American College of Nutrition 1997; 16 134-9.

33 Cruz CM, da Silva AF, dos Anjos LA. Basal metabolic rate is overestimated by predictive equation in college-age women of Rio de Janeiro, Brazil. Archivos Latinoamericanos de Nutricion 1999; 49: 232-7.

34 Cullinen K, Caldwell M. Weight training increases fat-free mass and strength in untrained young women. Journal of the American Dietetic Association 1998; 98: 414-8.

35 De Lorenzo A, Tagliabue A, Andreoli A, Testolin G, Comelli M, Deurenberg P. Measured and predicted resting metabolic rate in Italian males and females, aged 18-59 y. European Journal of Clinical Nutrition 2001; 55 : 208-14.

36 Della Bianca P, Jequier E, Schutz Y. Lack of metabolic and behavioral adaptations in rural Gambian men with low body mass index. American Journal of Clinical Nutrition 1994; 60: 37-42.

37 Deriaz O, Fournier G, Tremblay A, Despres JP, Bouchard C. Lean-body-mass composition and resting energy expenditure before and after long-term overfeeding. American Journal of Clinical Nutrition 1992; 56: 840-7.

38 Detzer MJ, Leitenberg H, Poehlman ET, Rosen JC, Silberg NT, Vara LS. Resting metabolic rate in women with bulimia nervosa: a cross-sectional and treatment study. American Journal of Clinical Nutrition 1994; 60: 327-32.

39 Diaz E, Goldberg GR, Taylor M, Savage JM, Sellen D, Coward WA. Effects of dietary supplementation on work performance in Gambian laborers. American Journal of Clinical Nutrition 1991; 53: 803-11.

40 Dionne IJ, Turner AN, Tchernof A, Pollin TI, Avrithi D, Gray D, Shuldiner AR, Poehlman ET. Identification of an interactive effect of beta3-and alpha2b-adrenoceptor gene polymorphisms on fat mass in Caucasian women. Diabetes 2001; 50: $91-5$.

41 Doi T, Matsuo T, Sugawara M, Matsumoto K, Minehira K, Hamada K, Okamura K, Suzuki M. New approach for weight reduction by a combination of diet, light resistance exercise and the timing of ingesting a protein supplement. Asia Pacific Journal of Clinical Nutrition 2001; 10: 226-32.

42 Dolezal BA, Potteiger JA. Concurrent resistance and endurance training influence basal metabolic rate in nondieting individuals. Journal of Applied Physiology 1998; 85: 695-700.

43 Dufour DL, Reina JC, Spurr G. Energy intake and expenditure of free-living, pregnant Colombian women in an urban setting. American Journal of Clinical Nutrition 1999; 70: 269-76.

44 Eck LH, Bennett AG, Egan BM, Ray JW, Mitchell CO, Smith MA, Klesges RC. Differences in macronutrient selections in users and nonusers of an oral contraceptive. American Journal of Clinical Nutrition 1997; 65: 419-24.

45 Ferro-Luzzi A, Petracchi C, Kuriyan R, Kurpad AV. Basal metabolism of weight-stable chronically undernourished men and women: lack of metabolic adaptation and ethnic differences. American Journal of Clinical Nutrition 1997; 66: $1086-93$

46 Fontaine E, Savard R, Tremblay A, Despres JP, Poehlman E, Bouchard C. Resting metabolic rate in monozygotic and dizygotic twins. Acta Geneticae Medicae et Gemellologiae 1985; 34: 41-7.

47 Fontvieille AM, Ferraro RT, Rising R, Larson DE, Ravussin E. Energy cost of arousal: effect of sex, race and obesity. International Journal of Obesity and Related Metabolic Disorders: Journal of the International Association for the Study of Obesity 1993; 17: 705-9.

48 Forsum E, Sadurskis A, Wager J. Resting metabolic rate and body composition of healthy Swedish women during pregnancy. American Journal of Clinical Nutrition 1988; 47: $942-7$.

49 Fox CS, Esparza J, Nicolson M, Bennett PH, Schulz LO, Valencia ME, Ravussin E. Is a low leptin concentration, a low resting metabolic rate, or both the expression of the "thrifty genotype"? Results from Mexican Pima Indians. American Journal of Clinical Nutrition 1998; 68: 1053-7.

50 Frigerio C, Schutz Y, Whitehead R, Jequier E. A new procedure to assess the energy requirements of lactation in Gambian women. American Journal of Clinical Nutrition 1991; 54: 526-33.

51 Frigerio C, Schutz Y, Whitehead R, Jequier E. Postprandial thermogenesis in lactating and non-lactating women from The Gambia. European Journal of Clinical Nutrition 1992; 46: $7-13$.

52 Fukagawa NK, Bandini LG, Young JB. Effect of age on body composition and resting metabolic rate. The American Journal of Physiology 1990; 259: E233-8.

53 Fuller NJ, Sawyer MB, Coward WA, Paxton P, Elia M. Components of total energy expenditure in free-living elderly men (over 75 years of age): measurement, predictability and relationship to quality-of-life indices. British Journal of Nutrition 1996; 75: 161-73.

54 Garrow JS, Webster JD. Effects on weight and metabolic rate of obese women of a $3.4 \mathrm{MJ}(800 \mathrm{kcal})$ diet. Lancet 1989; 1: 1429-31.

55 Gilliat-Wimberly M, Manore MM, Woolf K, Swan PD, Carroll SS. Effects of habitual physical activity on the resting metabolic rates and body compositions of women aged 35 to 50 years. Journal of the American Dietetic Association 2001; 101: 1181-8.

56 Goldberg GR, Prentice AM, Coward WA, Davies HL, Murgatroyd PR, Sawyer MB, Ashford J, Black AE. Longitudinal assessment of the components of energy 
balance in well-nourished lactating women. American Journal of Clinical Nutrition 1991; 54: 788-98.

57 Goldberg GR, Prentice AM, Coward WA, Davies HL, Murgatroyd PR, Wensing C, Black AE, Harding M, Sawyer M. Longitudinal assessment of energy expenditure in pregnancy by the doubly labelled water method. American Journal of Clinical Nutrition 1993; 57: 494-505.

58 Goldberg GR, Prentice AM, Murgatroyd PR, Haines W, Tuersley MD. Effects on metabolic rate and fuel selection of a selective beta-3 agonist (ICI D7114) in healthy lean men. International Journal of Obesity and Related Metabolic Disorders: Journal of the International Association for the Study of Obesity 1995; 19: 625-31.

59 Goldstone AP, Brynes AE, Thomas EL, Bell JD, Frost G, Holland A, Ghatei MA, Bloom SR. Resting metabolic rate, plasma leptin concentrations, leptin receptor expression, and adipose tissue measured by whole-body magnetic resonance imaging in women with Prader-Willi syndrome. American Journal of Clinical Nutrition 2002; 75: 468-75.

60 Goran MI, Beer WH, Wolfe RR, Poehlman ET, Young VR. Variation in total energy expenditure in young healthy freeliving men. Metabolism Clinical and Experimental 1993; 42: 487-96.

61 Goran MI, Calles-Escandon J, Poehlman ET, O'Connell M, Danforth E Jr. Effects of increased energy intake and/or physical activity on energy expenditure in young healthy men. Journal of Applied Physiology 1994; 77: 366-72.

62 Goris AH, Westerterp KR. Underreporting of habitual food intake is explained by under eating in highly motivated lean women. Journal of Nutrition 1999; 129: 878-82.

63 Gower BA, Nagy TR, Goran MI, Smith A, Kent E. Leptin in postmenopausal women: influence of hormone therapy, insulin, and fat distribution. Journal of Clinical Endocrinology and Metabolism 2000; 85: 1770-5.

64 Grinspoon S, Corcoran C, Miller K, Wang E, Hubbard J, Schoenfeld D, Anderson E, Basgoz N, Klibanski A. Determinants of increased energy expenditure in HIVinfected women. American Journal of Clinical Nutrition 1998; 68: 720-5.

65 Guillermo-Tuazon MA, Barba CV, van Raaij JM, Hautvast JG. Energy intake, energy expenditure, and body composition of poor rural Philippine women throughout the first 6 mo of lactation. American Journal of Clinical Nutrition 1992; 56: 874-80.

66 Hill JO, Peters JC, Yang D, Sharp T, Kaler M, Abumrad NN, Greene HL. Thermogenesis in humans during overfeeding with medium-chain triglycerides. Metabolism Clinical and Experimental 1989; 38: 641-8.

67 Horner NK, Lampe JW, Patterson RE, Neuhouser ML, Beresford SA, Prentice RL. Indirect calorimetry protocol development for measuring resting metabolic rate as a component of total energy expenditure in free-living postmenopausal women. Journal of Nutrition 2001; 131: $2215-8$.

68 Hunter GR, Weinsier RL, Gower BA, Wetzstein C. Agerelated decrease in resting energy expenditure in sedentary white women: effects of regional differences in lean and fat mass. American Journal of Clinical Nutrition 2001; 73 : $333-7$.

69 Illner K, Brinkmann G, Heller M, Bosy-Westphal A, Muller MJ. Metabolically active components of fat free mass and resting energy expenditure in nonobese adults. American Journal of Physiology. Endocrinology and Metabolism 2000; 278: E308-15.

70 Jobin N, de Jonge L, Garrel DR. Effects of RU 486 on energy expenditure and meal tolerance in normal men. Journal of the American College of Nutrition 1996; 15: 283-8.

71 Jorgensen JO, Vahl N, Dall R, Christiansen JS. Resting metabolic rate in healthy adults: relation to growth hormone status and leptin levels. Metabolism Clinical and Experimental 1998; 47: 1134-9.

72 Kanade AN, Gokhale MK, Rao S. Energy costs of standard activities among Indian adults. European Journal of Clinical Nutrition 2001; 55: 708-13.

73 Karlsson C, Stenlof K, Johannsson G, Marin P, Bjorntorp P, Bengtsson BA, Carlsson B, Carlsson LM, Sjostrom L. Effects of growth hormone treatment on the leptin system and on energy expenditure in abdominally obese men. European Journal of Endocrinology: European Federation of Endocrine Societies 1998; 138: 408-14.

74 Kashiwazaki H, Dejima Y, Suzuki T. Influence of upper and lower thermoneutral room temperatures ( 20 degrees $\mathrm{C}$ and 25 degrees C) on fasting and post-prandial resting metabolism under different outdoor temperatures. European Journal of Clinical Nutrition 1990; 44: 405-13.

75 Katzmarzyk PT, Perusse L, Tremblay A, Bouchard C. No association between resting metabolic rate or respiratory exchange ratio and subsequent changes in body mass and fatness: 5-1/2 year follow-up of the Quebec family study. European Journal of Clinical Nutrition 2000; 54: 610-4.

76 Katzmarzyk PT, Rankinen T, Perusse L, Deriaz O, Tremblay A, Borecki I, Rao DC, Bouchard C. Linkage and association of the sodium potassium-adenosine triphosphatase alpha2 and beta1 genes with respiratory quotient and resting metabolic rate in the Quebec Family Study. Journal of Clinical Endocrinology and Metabolism 1999; 84: 2093-7.

77 Kerckhoffs DA, Blaak EE, Van Baak MA, Saris WH. Effect of aging on beta-adrenergically mediated thermogenesis in men. American Journal of Physiology 1998; 274: E1075-9.

78 Kinabo JL, Durnin JV. Thermic effect of food in man: effect of meal composition, and energy content. British Journal of Nutrition 1990; 64: 37-44.

79 Klausen B, Toubro S, Astrup A. Age and sex effects on energy expenditure. American Journal of Clinical Nutrition 1997; 65: 895-907.

80 Kriketos AD, Sharp TA, Seagle HM, Peters JC, Hill JO. Effects of aerobic fitness on fat oxidation and body fatness. Medicine and Science in Sports and Exercise 2000; 32: 805-11.

81 Lawrence M, Thongprasert K, Durnin JV. Between-group differences in basal metabolic rates: an analysis of data collected in Scotland, the Gambia and Thailand. European Journal of Clinical Nutrition 1988; 42: 877-91.

82 Lemmer JT, Ivey FM, Ryan AS, Martel GF, Hurlbut DE, Metter JE, Fozard JL, Fleg JL, Hurley BF. Effect of strength training on resting metabolic rate and physical activity: age and gender comparisons. Medicine and Science in Sports and Exercise 2001; 33: 532-41.

83 Li ET, Tsang LB, Lui SS. Resting metabolic rate and thermic effects of a sucrose-sweetened soft drink during the menstrual cycle in young Chinese women. Canadian Journal of Physiology and Pharmacology 1999; 77: 544-50.

84 Liuzzi A, Savia G, Tagliaferri M, et al. Serum leptin concentration in moderate and severe obesity: relationship with clinical, anthropometric and metabolic factors. International Journal of Obesity and Related Metabolic Disorders: Journal of the International Association for the Study of Obesity 1999; 23: 1066-73.

85 Livingstone MB, Strain JJ, Prentice AM, Coward WA, Nevin GB, Barker ME, Hickey R, McKenna PG, Whitehead RG. Potential contribution of leisure activity to the energy expenditure patterns of sedentary populations. British Journal of Nutrition 1991; 65: 145-55.

86 Lovelady CA, Nommsen-Rivers LA, McCrory MA, Dewey KG. Effects of exercise on plasma lipids and metabolism of lactating women. Medicine and Science in Sports and Exercise 1995; 27: 22-8.

87 Luhrmann PM, Herbert BM, Gaster C, Neuhauser-Berthold M. Validation of a self-administered 3-day estimated dietary 
record for use in the elderly. European Journal of Nutrition 1999; 38: 235-40.

88 Luke A, Rotimi CN, Adeyemo AA, Durazo-Arvizu RA, Prewitt TE, Moragne-Kayser L, Harders R, Cooper RS. Comparability of resting energy expenditure in Nigerians and US blacks. Obesity Research 2000; 8: 351-9.

89 Lundholm K, Holm G, Lindmark L, Larsson B, Sjostrom L, Bjorntorp P. Thermogenic effect of food in physically well-trained elderly men. European Journal of Applied Physiology and Occupational Physiology 1986; 55: 486-92.

90 Manore MM, Berry TE, Skinner JS, Carroll SS. Energy expenditure at rest and during exercise in nonobese female cyclical dieters and in nondieting control subjects. American Journal of Clinical Nutrition 1991; 54: 41-6.

91 Marra M, Scalfi L, Covino A, Esposito-Del Puente A, Contaldo F. Fasting respiratory quotient as a predictor of weight changes in non-obese women. International Journal of Obesity and Related Metabolic Disorders: Journal of the International Association for the Study of Obesity 1998; 22: 601-3.

92 Mawson JT, Braun B, Rock PB, Moore LG, Mazzeo R, Butterfield GE. Women at altitude: energy requirement at 4,300 m. Journal of Applied Physiology 2000; 88: 272-81.

93 McCrory MA, Kim HR, Wright NC, Lovelady CA, Aitkens S, Kilmer DD. Energy expenditure, physical activity, and body composition of ambulatory adults with hereditary neuromuscular disease. American Journal of Clinical Nutrition 1998; 67: 1162-9.

94 McNeill G, Rivers JP, Payne PR, de Britto JJ, Abel R. Basal metabolic rate of Indian men: no evidence of metabolic adaptation to a low plane of nutrition. Human Nutrition: Clinical Nutrition 1987; 41: 473-83.

95 Minghelli G, Schutz Y, Charbonnier A, Whitehead R, Jequier E. Twenty-four-hour energy expenditure and basal metabolic rate measured in a whole-body indirect calorimeter in Gambian men. American Journal of Clinical Nutrition 1990; 51: 563-70.

96 Moffatt RJ, Owens SG. Cessation from cigarette smoking: changes in body weight, body composition, resting metabolism, and energy consumption. Metabolism Clinical and Experimental 1991; 40: 465-70.

97 Morales AJ, Haubrich RH, Hwang JY, Asakura H, Yen SS The effect of six months treatment with a $100 \mathrm{mg}$ daily dose of dehydroepiandrosterone (DHEA) on circulating sex steroids, body composition and muscle strength in ageadvanced men and women. Clinical Endocrinology 1998; 49: 421-32.

98 Murray LA, Reilly JJ, Choudhry M, Durnin JV. A longitudinal study of changes in body composition and basal metabolism in physically active elderly men. European Journal of Applied Physiology and Occupational Physiology 1996; 72: 215-18.

99 Myerson M, Gutin B, Warren MP, May MT, Contento I, Lee M, Pi-Sunyer FX, Pierson RN Jr, Brooks-Gunn J. Resting metabolic rate and energy balance in amenorrheic and eumenorrheic runners. Medicine and Science in Sports and Exercise 1991; 23: 15-22.

100 Nicklas BJ, van Rossum EF, Berman DM, Ryan AS, Dennis KE, Shuldiner AR. Genetic variation in the peroxisome proliferator-activated receptor-gamma 2 gene (Pro12Ala) affects metabolic responses to weight loss and subsequent weight regain. Diabetes 2001; 50: 2172-6.

101 Nielsen S, Hensrud DD, Romanski S, Levine JA, Burguera B, Jensen MD. Body composition and resting energy expenditure in humans: role of fat, fat-free mass and extracellular fluid. International Journal of Obesity and Related Metabolic Disorders: Journal of the International Association for the Study of Obesity 2000; 24: $1153-7$.
102 Nixon DW, Kutner M, Heymsfield S, et al. Resting energy expenditure in lung and colon cancer. Metabolism Clinical and Experimental 1988; 37: 1059-64.

103 Owen OE, Holup JL, D’Alessio DA, Craig ES, Polansky M, Smalley KJ, Kavle EC, Bushman MC, Owen LR, Mozzoli MA. A reappraisal of the caloric requirements of men. American Journal of Clinical Nutrition 1987; 46: 875-85.

104 Owen OE, Kavle E, Owen RS, Polansky M, Caprio S, Mozzoli MA, Kendrick ZV, Bushman MC, Boden G. A reappraisal of caloric requirements in healthy women. American Journal of Clinical Nutrition 1986; 44: 1-19.

105 Ozeki O, Ebisawa L, Ichikawa M, Nagasawa N, Sato F, Fujita Y. Physical activities and energy expenditures of institutionalized Japanese elderly women. Journal of Nutritional Science and Vitaminology 2000; 46: 188-92.

106 Pelkman CL, Chow M, Heinbach RA, Rolls BJ. Short-term effects of a progestational contraceptive drug on food intake, resting energy expenditure, and body weight in young women. American Journal of Clinical Nutrition 2001; 73: 19-26.

107 Piers LS, Diffey B, Soares MJ, Frandsen SL, McCormack LM, Lutschini MJ, O'Dea K. The validity of predicting the basal metabolic rate of young Australian men and women. European Journal of Clinical Nutrition 1997; 51: 333-7.

108 Piers LS, Diggavi SN, Rijskamp J, van Raaij JM, Shetty PS, Hautvast JG. Resting metabolic rate and thermic effect of a meal in the follicular and luteal phases of the menstrual cycle in well-nourished Indian women. American Journal of Clinical Nutrition 1995; 61: 296-302.

109 Piers LS, Diggavi SN, Thangam S, van Raaij JM, Shetty PS, Hautvast JG. Changes in energy expenditure, anthropometry, and energy intake during the course of pregnancy and lactation in well-nourished Indian women. American Journal of Clinical Nutrition 1995; 61: $501-13$.

110 Piers LS, Shetty PS. Basal metabolic rates of Indian women. European Journal of Clinical Nutrition 1993; 47 586-91

111 Poehlman ET, Arciero PJ, Melby CL, Badylak SF. Resting metabolic rate and postprandial thermogenesis in vegetarians and nonvegetarians. American Journal of Clinical Nutrition 1988; 48: 209-13.

112 Poehlman ET, Gardner AW, Ades PA, Katzman-Rooks SM, Montgomery SM, Atlas OK, Ballor DL, Tyzbir RS. Resting energy metabolism and cardiovascular disease risk in resistance-trained and aerobically trained males. Metabolism: Clinical and Experimental 1992; 41: 1351-60.

113 Poehlman ET, Melby CL, Badylak SF. Relation of age and physical exercise status on metabolic rate in younger and older healthy men. Journal of Gerontology 1991; 46 : B54-8.

114 Poehlman ET, Scheffers J, Gottlieb SS, Fisher ML, Vaitekevicius P. Increased resting metabolic rate in patients with congestive heart failure. Annals of Internal Medicine 1994; 121: 860-2.

115 Poehlman ET, Toth MJ. Mathematical ratios lead to spurious conclusions regarding age-and sex-related differences in resting metabolic rate. American Journal of Clinical Nutrition 1995; 61: 482-5.

116 Poehlman ET, Toth MJ, Gardner AW. Changes in energy balance and body composition at menopause: a controlled longitudinal study. Annals of Internal Medicine 1995; 123: 673-5.

117 Poehlman ET, Toth MJ, Webb GD. Sodium-potassium pump activity contributes to the age-related decline in resting metabolic rate. Journal of Clinical Endocrinology and Metabolism 1993; 76: 1054-7.

118 Poehlman ET, Tremblay A, Fontaine E, Despres JP, Nadeau A, Dussault J, Bouchard C. Genotype dependency of the thermic effect of a meal and associated hormonal changes 
following short-term overfeeding. Metabolism Clinical and Experimental 1986; 35: 30-6.

119 Poehlman ET, Tremblay A, Nadeau A, Dussault J, Theriault G, Bouchard C. Heredity and changes in hormones and metabolic rates with short-term training. American Journal of Physiology 1986; 250: E711-7.

120 Polito A, Fabbri A, Ferro-Luzzi A, Cuzzolaro M, Censi L, Ciarapica D, Fabbrini E, Giannini D. Basal metabolic rate in anorexia nervosa: relation to body composition and leptin concentrations. American Journal of Clinical Nutrition 2000; 71: 1495-502.

121 Poppitt SD, Livesey G, Elia M. Energy expenditure and net substrate utilization in men ingesting usual and high amounts of nonstarch polysaccharide. American Journal of Clinical Nutrition 1998; 68: 820-6.

122 Prentice AM, Black AE, Coward WA, Davies HL, Goldberg GR, Murgatroyd PR, Ashford J, Sawyer M, Whitehead RG. High levels of energy expenditure in obese women. British Medical Journal 1986; 292: 983-7.

123 Pullicino E, Copperstone C, Luzi L, McNeill G, Elia M. Relationship between anthropometric indices of body fat distribution and basal energy metabolism in healthy Maltese women. Acta Diabetologica 1996; 33: 198-204.

124 Ratheiser KM, Brillon DJ, Campbell RG, Matthews DE. Epinephrine produces a prolonged elevation in metabolic rate in humans. American Journal of Clinical Nutrition 1998; 68: 1046-52.

125 Reeves SL, Henry CJ. Dietary change, energy balance and body weight regulation among migrating students. International Journal of Food Sciences and Nutrition 2000; 51: 429-38.

126 Rising R, Harper IT, Fontvielle AM, Ferraro RT, Spraul M, Ravussin E. Determinants of total daily energy expenditure: variability in physical activity. American Journal of Clinical Nutrition 1994; 59: 800-4.

127 Rothenberg EM, Bosaeus IG, Westerterp KR, Steen BC. Resting energy expenditure, activity energy expenditure and total energy expenditure at age 91-96 years. British Journal of Nutrition 2000; 84: 319-24.

128 Rush EC, Plank LD, Coward WA. Energy expenditure of young Polynesian and European women in New Zealand and relations to body composition. American Journal of Clinical Nutrition 1999; 69: 43-8.

129 Saad MF, Alger SA, Zurlo F, Young JB, Bogardus C, Ravussin E. Ethnic differences in sympathetic nervous system-mediated energy expenditure. American Journal of Physiology 1991; 261: E789-94.

130 Sanchez-Castillo CP, Franklin M, McNeill G, Solano MD, Bonner S, Lopez N, Davidson L, James WPT. Are the proposed limits of energy intake: basal metabolic rate and dietary nitrogen:urinary nitrogen ratios suitable for validation of food intake? British Journal of Nutrition 2001; 85: 725-31.

131 Sathyaprabha TN. Basal metabolic rate and body composition in elderly Indian males. Indian Journal of Physiology and Pharmacology 2000; 44: 179-84.

132 Schmidt WD, O'Connor PJ, Cochrane JB, Cantwell M. Resting metabolic rate is influenced by anxiety in college men. Journal of Applied Physiology 1996; 80: 638-42.

133 Schultink JW, Van Raaii JM, Hautvast JG. Seasonal weight loss and metabolic adaptation in rural Beninese women: the relationship with body mass index. British Journal of Nutrition 1993; 70: 689-700.

134 Schulz LO, Nyomba BL, Alger S, Anderson TE, Ravussin E. Effect of endurance training on sedentary energy expenditure measured in a respiratory chamber. American Journal of Physiology 1991; 260: E257-61.

135 Seale JL, Conway JM. Relationship between overnight energy expenditure and BMR measured in a room-sized calorimeter. European Journal of Clinical Nutrition 1999; 53: $107-11$.

136 Segal KR, Chun A, Coronel P, Cruz-Noori A, Santos R. Reliability of the measurement of postprandial thermogenesis in men of three levels of body fatness. Metabolism Clinical and Experimental 1992; 41: 754-62.

137 Segal KR, Dunaif A. Resting metabolic rate and postprandial thermogenesis in polycystic ovarian syndrome. International Journal of Obesity 1990; 14: 559-67.

138 Seidell JC, Muller DC, Sorkin JD, Andres R. Fasting respiratory exchange ratio and resting metabolic rate as predictors of weight gain: the Baltimore Longitudinal Study on Aging. International Journal of Obesity and Related Metabolic Disorders: Journal of the International Association for the Study of Obesity 1992; 16: 667-74.

139 Singh J, Prentice AM, Diaz E, Coward WA, Ashford J, Sawyer M, Whitehead RG. Energy expenditure of Gambian women during peak agricultural activity measured by the doubly labelled water method. British Journal of Nutrition 1989; 62: 315-29.

140 Singhal A, Davies P, Wierenga KJ, Thomas P, Serjeant G. Is there an energy deficiency in homozygous sickle cell disease? American Journal of Clinical Nutrition 1997; 66: 386-90.

141 Smith DA, Dollman J, Withers RT, Brinkman M, Keeves JP, Clark DG. Relationship between maximum aerobic power and resting metabolic rate in young adult women. Journal of Applied Physiology 1997; 82: 156-63.

142 Smith DA, Withers RT, Brinkman M, Tucker RC, Chatterton BE, Schultz CG, Clark DG. Resting metabolic rate, body composition and aerobic fitness comparisons between active and sedentary 54-71 year old males. European Journal of Clinical Nutrition 1999; 53: 434-40.

143 Soares MJ, Piers LS, O'Dea K, Shetty PS. No evidence for an ethnic influence on basal metabolism: an examination of data from India and Australia. British Journal of Nutrition 1998; 79: 333-41.

144 Soares MJ, Shetty PS. Long-term stability of metabolic rates in young adult males. Human Nutrition Clinical Nutrition 1987; 41: 287-90.

145 Spaaij CJ, van Raaij JM, Van der Heijden LJ, Schouten FJM, Drijvers JJMM, de Groot LCPGM, Boekholt HA, Hautvast JGAJ. No substantial reduction of the thermic effect of a meal during pregnancy in well-nourished Dutch women. British Journal of Nutrition 1994; 71: 335-44.

146 Spaanderman ME, Meertens M, van Bussel M, Ekhart TH, Peeters LL. Cardiac output increases independently of basal metabolic rate in early human pregnancy. American Journal of Physiology. Heart and Circulatory Physiology 2000; 278: H1585-8.

147 Spurr GB, Dufour DL, Reina JC, Hoffmann RG, Waslien CI, Staten LK. Variation of the basal metabolic rate and dietary energy intake of Colombian women during 1 y. American Journal of Clinical Nutrition 1994; 59: 20-7.

148 Stenlof K, Sjostrom L, Fagerberg B, Nystrom E, Lindstedt G. Thyroid hormones, procollagen III peptide, body composition and basal metabolic rate in euthyroid individuals. Scandinavian Journal of Clinical and Laboratory Investigation 1993; 53: 793-803.

149 Strickland SS, Duffield AE. Anthropometric status and resting metabolic rate in users of the areca nut and smokers of tobacco in rural Sarawak. Annals of Human Biology 1997; 24: 453-74.

150 Strickland SS, Ulijaszek SJ. Energetic cost of standard activities in Gurkha and British soldiers. Annals of Human Biology 1990; 17: 133-44.

151 Sujatha T, Shatrugna V, Venkataramana Y, Begum N. Energy expenditure on household, childcare and occu- 
pational activities of women from urban poor households. British Journal of Nutrition 2000; 83: 497-503.

152 Svensson J, Lonn L, Jansson JO, Murphy G, Wyss D, Krupa D, Cerchio K, Polvino W, Gertz B, Boseaus I, Sjöström L, Bengtsson BA. Two-month treatment of obese subjects with the oral growth hormone (GH) secretagogue MK-677 increases GH secretion, fat-free mass, and energy expenditure. Journal of Clinical Endocrinology and Metabolism 1998; 83: 362-9.

153 Tataranni PA, Larson DE, Ravussin E. Body fat distribution and energy metabolism in obese men and women. Journal of the American College of Nutrition 1994; 13: 569-74.

154 Thompson JL, Gylfadottir UK, Moynihan S, Jensen CD, Butterfield GE. Effects of diet and exercise on energy expenditure in postmenopausal women. American Journal of Clinical Nutrition 1997; 66: 867-73.

155 Toth MJ, Gardner AW, Poehlman ET. Training status, resting metabolic rate, and cardiovascular disease risk in middle-aged men. Metabolism Clinical and Experimental 1995; 44: 340-7.

156 Toth MJ, Poehlman ET. Resting metabolic rate and cardiovascular disease risk in resistance-and aerobictrained middle-aged women. International Journal of Obesity and Related Metabolic Disorders: Journal of the International Association for the Study of Obesity 1995; 19: 691-8.

157 Toth MJ, Poehlman ET. Sympathetic nervous system activity and resting metabolic rate in vegetarians. Metabolism Clinical and Experimental 1994; 43: 621-5.

158 van der Ploeg GE, Gunn SM, Withers RT, Modra AC, Keeves JP, Chatterton BE. Predicting the resting metabolic rate of young Australian males. European Journal of Clinical Nutrition 2001; 55: 145-52.

159 van Pelt RE, Dinneno FA, Seals DR, Jones PP. Age-related decline in RMR in physically active men: relation to exercise volume and energy intake. American Journal of Physiology. Endocrinology and Metabolism 2001; 281: E633-9.

160 van Raaij JM, Schonk CM, Vermaat-Miedema SH, Peek ME, Hautvast JG. Body fat mass and basal metabolic rate in Dutch women before, during, and after pregnancy: a reappraisal of energy cost of pregnancy. American Journal of Clinical Nutrition 1989; 49: 765-72.

161 van Raaij JM, Schonk CM, Vermaat-Miedema SH, Peek ME, Hautvast JG. Energy cost of physical activity throughout pregnancy and the first year postpartum in Dutch women with sedentary lifestyles. American Journal of Clinical Nutrition 1990; 52: 234-9.

162 Velthuis-te Wierik EJ, Westerterp KR, van den Berg H. Impact of a moderately energy-restricted diet on energy metabolism and body composition in non-obese men. International Journal of Obesity and Related Metabolic Disorders: Journal of the International Association for the Study of Obesity 1995; 19: 318-24.

163 Visser M, Deurenberg P, van Staveren WA, Hautvast JG. Resting metabolic rate and diet-induced thermogenesis in young and elderly subjects: relationship with body composition, fat distribution, and physical activity level. American Journal of Clinical Nutrition 1995; 61: 772-8.

164 Volpe SL, Huang HW, Larpadisorn K, Lesser II. Effect of chromium supplementation and exercise on body composition, resting metabolic rate and selected biochemical parameters in moderately obese women following an exercise program. Journal of the American College of Nutrition 2001; 20: 293-306.

165 Voorrips LE, van Acker TM, Deurenberg P, van Staveren WA. Energy expenditure at rest and during standardized activities: a comparison between elderly and middle-aged women. American Journal of Clinical Nutrition 1993; 58 $15-20$.

166 Wahrlich V, Anjos LA. Validation of predictive equations of basal metabolic rate of women living in Southern Brazil. Revista de Saude Publica 2001; 35: 39-45.

167 Webb GD, Poehlman ET, Tonino RP. Dissociation of changes in metabolic rate and blood pressure with erythrocyte $\mathrm{Na}-\mathrm{K}$ pump activity in older men after endurance training. Journal of Gerontology 1993; 48 M47-M52.

168 Welle S, Forbes GB, Statt M, Barnard RR, Amatruda JM. Energy expenditure under free-living conditions in normal-weight and overweight women. American Journal of Clinical Nutrition 1992; 55: 14-21.

169 Welle S, Nair KS. Relationship of resting metabolic rate to body composition and protein turnover. American Journal of Physiology 1990; 258: E990-8.

170 Welle S, Thornton C, Totterman S, Forbes G. Utility of creatinine excretion in body-composition studies of healthy men and women older than $60 \mathrm{y}$. American Journal of Clinical Nutrition 1996; 63: 151-6.

171 Weststrate JA, Weys PJ, Poortvliet EJ, Deurenberg P, Hautvast JG. Diurnal variation in postabsorptive resting metabolic rate and diet-induced thermogenesis. American Journal of Clinical Nutrition 1989; 50: 908-14.

172 Williamson DL, Kirwan JP. A single bout of concentric resistance exercise increases basal metabolic rate 48 hours after exercise in healthy 59-77-year-old men. Journals of Gerontology. Series A, Biological Sciences and Medical Sciences 1997; 52: M352-5.

173 Wilmore JH, Stanforth PR, Hudspeth LA, Gagnon J, Daw EW, Leon AS, Rao DC, Skinner JS, Bouchard C. Alterations in resting metabolic rate as a consequence of $20 \mathrm{wk}$ of endurance training: the HERITAGE Family Study. American Journal of Clinical Nutrition 1998; 68: 66-71.

174 Withers RT, Smith DA, Tucker RC, Brinkman M, Clark DG. Energy metabolism in sedentary and active 49- to 70-yrold women. Journal of Applied Physiology 1998; 84: 1333-40.

175 Yamauchi T, Umezaki M, Ohtsuka R. Influence of urbanisation on physical activity and dietary changes in Huli-speaking population: a comparative study of village dwellers and migrants in urban settlements. British Journal of Nutrition 2001; 85: 65-73. 